\title{
Trade Liberalisation and Economic Growth, an Emperical Analysis
}

\author{
Helder Eduardo Pinto Afonso \\ Institute of Governance, Humanities and Social Science, the Pan African University
}

\begin{abstract}
The issues in the achievement of an economic performance are underpinned by the success of different actions that are employed by the nations and its regional groups. In line with this goal, different economic schemes are applied to address the needs of growth performance. Therefore, it is important to understand the different challenges that can affect economic performance of a country and the issues of trade liberalization. This research examines the influence of openness to trade and growth performance. Thus, in this scenario the paper looked at different papers that analyses countries trading policies and the various strategies under liberalisation plan and its effect on economic growth. The empirical findings from various studies indicated that trade openness canaffect negatively economic growth, although, it showed that having a strong manufactural sector and industry, may create a positive impact on growth.
\end{abstract}

Key words: Openness, trade liberalisation and economic growth

\section{INTRODUCTION}

$\mathrm{T}$ he issues on growth and trade liberalisation have been a matter of debate for a while now, it is not new at all. Mallick and Ranjan (2019) affirmed that it is "inconclusive and theoretically controversial". Academicians and scholars from the past and the current century have been arguing whether openness to trade would create economic growth. Sachs and Warner have contributed

Significantly to the studies of the relationship of these variables (Semancíková et al., 2016). Although, there is a lack of conceptualization and theoretical framework that links how trade liberalisation or joining a regional economic group can be proportionate to economic growth. Intellectuals have considered the relevant problems associated with the measurement of openness to trade and economic growth, and to some degree, economists and some policymakers believe that trade protection does not help the country's economic growth.

Nations decide whether to join a regional group and it reflects on the adoption of different ideologies that align with the interests of a country and its specific vision. However, to liberalise or to protect the economy always appears to be the reaction of any state (Rodrik, 2017). Thus, the research carried out a study aimed at analysing the implications or the extent to openness to trade affects an economy. While trade liberalisation hasbeen one of the most used policy, few indicators can describe the relationship between trade and economic growth.
However, this paper seeks to look at the grounds of an interactive complement that relies on the issue of the relationship of openness and economic growth of a specific country. The objectives of this study are:

i. To examine the relationship between openness to trade and economic growth.

ii. To analyse studies on the impact openness trade on Economic growth.

iii. To investigate the negative impact of trade on economic growth.

The research is comprised of four sections, Section 1, General Introduction, provides the reader with background information to contextualize the study, and subsequently the research rationale and significance of the study. The research objectives are discussed, and the underlying research question is mentioned, along with its supporting sub-questions.

Section 2, Literature Review, provides an examination of important literature regarding economic growth, trade liberalisation and openness, its relationship, and implications.

Section 3, Empirical analysis This was obtained from the literature review and the empirical studies collected from different papers. More also, an in-depth discussion on the empirical studies on trade and growth.

Section 4, Conclusion, provides an overall conclusion of the study. This is done by drawing out findings or the main points of the study in accordance with the research objectives.

\section{LITERATURE REVIEW}

\subsection{Empirical Studies}

Before analysing the theoretical and empirical existence of the impact of trade openness, trade liberalisation on economic growth, it is important to come up with the definitions or in fact, the main questions that academicians are facing regarding the concepts of trade liberalisation and openness as well as the huge debate on growth and its conceptual approaches varying from the different schools of thoughts. Conceptualists have strongly argued on the importance of defining trade liberalisation and openness, some consider them to be different, and there have been lots of confusion when it comes to their definitions. The paper looks around the concepts for a better understand them throughout the study. Edwards (1998) argued on the issue of understanding trade liberalisation as he says that it is more of severe reduction of 
import tariffs to a uniform level of 10 per cent.Talukder (2013) opined that trade liberalisation refers to the reduction of trade barriers that have been created over a few years by countries around the world. Pigka et al.,(2013) considered that "trade liberalisation includes policy measures to increase trade openness while increased trade openness is usually considered as an increase in the size of the country's trade sectors in relation to the total output" even though, the concept looks like openness to trade. But Semancíkováet al.(2016) affirmed that "openness to trade is closely related to export and import as the most used definition to openness is the sum of export and import to GDP of a country" and according to Stiglitz (2012) trade liberalisation is supposed to enhance a country's income by forcing resources to move from less productive uses to more productive uses.

\section{EMPIRICAL ANALYSIS}

\subsection{Trade and Openness to Trade}

The fact that, trade or free market initiatives started long ago and had a strong expression after the great depression and the rise of WTO, Kishtainy et al. (2015) said that the so-called new consensus started in 2000 and prevailed over the macroeconomics that emphasized on the limited role of the state. Thus, the question of trade has been around for a very long time, it is not a contemporaneous issue that many key thinkers have been considering since. For instance, in the 1620s Gerald de Malynes claimed that England should regulate external trade to stop the nation's gold and silver going overseas. In 1791 the US Secretary of the Treasury, Alexander Hamilton contended for the protection of fresh industries, and Milton Friedman insisted that trade helps developing countries. Nevertheless, the fall of the global economy during the Great Depression and the break down in the cooperation between economies was an important period for the trade era. In addition, Kishtainy et al. (2015) discussed international trade and Bretton Woods and brought the thought that in the wake of war and depression, nations must cooperate. The Bretton Woods Conference in July 1944, in Bretton Woods, New Hampshire, USA, and the birth of the International Monetary Fund (IMF), the World Bank, and later in 1947, the World Trade Organization (WTO), which came from the General Agreement on Tariff and Trade (GATT). The GATT has never achieved the trade liberalisation as it was planned, however, the WTO would have it forward, not limiting itself to a mere agreement, but the WTO has established a Dispute Settlement Body (Deodhar, 2018).

The history behind the formation of the WTO is still a matter of huge debate for academicians and policy makers, from the end of the World War II, the establishment of these international organizations would smoothen and control international trade and financial environment. Stiglitz (2012) opined that they have become more political, and many scholars disagree with free trade, even though, theoretically it can sound very correct, what is seen is that countries try to keep their own market and apply policies that block imports and exports. In fact, the benefits of trade have been a matter of discussion not only at the academic level but also at political level. Barnerjee and Duflo (2019) stated that more trade is good, and the Adam Smith's view basically looked at the fact that what really matters is the wealth of the nations and not of an individual nation as he argued that the market would always try to enrich all countries eventually. Smith's ideology has been dominating from what is seen from the western economies (Kishtainy et al., 2015).

The concept of integration leads us to a gradual understanding of the perception of openness and trade liberalisation. (Jenkins et al., 2002). In fact, scholars consider theories of comparative advantage and specialisation as approaches to analyse trade and economic growth. Adam Smith poses the question of what makes the economies prosper, also he first introduced the concept of specialization in economics as an individual perspective, in his book "The Wealth of Nations" where he broke down the role of trade in enabling the specialisation. Paul Romer and Robert Lucas introduced the Endogenous Growth Theory where they strongly affirm that growth is primarily the result of internal factors (Kishtainy et al., 2015). David Ricardo breaks it down to a macroeconomic perspective, where his analysis reflects how countries specialise and enter a trade based on opportunity cost. Stonecash et al., (2000) emphasized on what Adam Smith spoke of, a tolerable administration of justice, not a perfect justice where the market liberalisation is primary. He also argued on the issue that African countries grew slowly due to much higher trade barriers, and excessive tax rates. Additionally, in a long-term scale, growth predicament is extremely related to the extent of overall market orientation, including openness to trade, domestic trade liberalisation, private rather than state ownership and the protection of private property rights.

By analysing trade and its issues, it is important to understand that external forces have influenced significantly national economies to open, in fact, it is seen that globalisation and its forces have created an environment where nations are no longer isolated. Moreover, the governance and economic schemes of the states have been influenced to enter the borderless world system and Stiglitz (2012) stated that globalisation has been accompanied by the creation of new institutions that have joined existing ones to work across borders. Semancíková (2016) said that international trade affects economic growth of the countries positively, bringing more capital accumulation, industrialization, technological progress, and institutional development. The opened countries have more inclination to be more productive and to apply comparative advantages. Moreover, it is believed that economies that are opened expand more rapidly than those which are closed, these benefits are strongly debated due to the issue of perception of the tangible benefits of trade. An OECD report on trade states that "trade has contributed to lifting hundreds of millions of people out of poverty: the share 
of the world's population living on less than PPP USD 1.90 per day fell from around $35 \%$ in 1990 to less than $10 \%$ in 2015. evidence on the impact of trade on poverty in developing countries"1. Rodriguez and Rodrik (2001) brought up a point that explores results that can lead us to a different interpretation, as well as the understanding that the link between trade and growth have serious shortcomings. Likewise, Talukder (2013) showed that the supporters of trade liberalisation analysing the shift on the way to a more open exchange or trade system, confers significant gains and he calls them static and dynamic gains to the economy. The author also suggests that the static benefits from openness are explained by neo-classical trade theories. Additionally, he mentions that this advocacy for free trade was based not only on the Ricardian principle of comparative advantage but also on the argument that free trade would contribute to development through competition and learning.

Different studies have brought different views on the relationship between trade, openness to trade and economic growth, although there have been numerous results on the matter; the studies are described from the perspective of two groups. The first group strongly agrees with the positive impact of trade openness on growth or a relationship between trade and growth, and the second group is composed of the authors that are strongly sceptical on the matter. The main studies on this matter are known as the ones focused on the developing countries such as some in Africa, Asia, and Latin American countries. This, in fact, was mainly for analysing a long-term link between the variables and the studies have been significantly aligned to the IMF and World Bank agenda. There have been criticisms on the econometric analysis that do not bring significant or positive correlation between trade liberalisation and growth. Furthermore, the studies of Dollar and Kraay (2001) and back to Edwards (1998) have found out, empirically that the sources of growth in the developing countries were mainly related to openness to trade i.e., they concluded that there is an empirical relationship and a positive impact on growth.

There are studies that also focus on the matter of the impact of trade openness on growth, but to some extent consider that there has been no empirical evidence on this matter. Rodriguez and Rodrik (2001) showed that this positive relationship is not robust as the openness measures seems to be problematic and lack appropriate control variables. There have been different opinions from scholars when it comes to trade, and some of them may perhaps be very sceptical, and completely disagree that poor countries would grow their economies if they opened their borders to trade. The German economist Friedrich List long ago had contended against free

\footnotetext{
${ }^{1}$ An OCED report on "Why open markets matter" under the topic trade and the subtopic understanding the global trading system. Accessed through. https://www.oecd.org/trade/understanding-the-global-trading-system/whyopen-markets-

matter/\#: : :text=Relatively\%20open\%20economies\%20grow\%20faster,stabili ty $\% 20$ and $\% 20$ security $\% 20$ for $\% 20$ everyone.
}

trade and for protectionism in internal markets. It is also seen that wealthy countries are in a major position, so they take advantage of the poor countries through unequal trading conditions. Therefore, the relationship between openness to trade and economic growth is not well seen in the perspective of Friedrich List, hence some scholars can discuss on the issues of the dependence theory, as well as the World-SystemTheory. In fact, Hans Singer and Raúl Prebisch claim that trade between poor and rich countries deteriorate over time. This issue of trade benefiting the growth of rich western countries as for the scholar Immanuel Wallerstein described using the world-system theory which explains how rich countries impoverish the poor. In addition to that, some scholars have seen that trade liberalisation policies always lead to situations where the wealthy countries benefit, and not just a specific one as per the dependency theory. This worldsystem theory refines the Marxist aspect of the dependence theory, which argues, in opposition to free market (Kishtainy et al., 2015). In so doing, the two US economists Dollar et al. (2001) have discussed in the past decades that trade has helped developing countries to grow and reduce poverty; they focused on the point that the countries that cut tariffs would have grown faster and seen less poverty. However, these have been a contradictory approach between the theory and the practice (Stiglitz, 2012).

Furthermore, openness to trade or trade liberalisation has been under severe criticism because there is what is called impractical assumptions, such as perfect competition and constant return to scale, associated with the neo-classical Heckscher-Ohlin model of comparative advantage as stated by Talukder (2013). Additionally, while traditional knowledge predicts a growth-increasing effect of trade, latest improvements suggest that trade openness is not always beneficial to economic growth (Zahonogo, 2016). Thus, the gains and pains of trade are clear and as Barnerjee \& Duflo (2019) opined, they do see the advantages of being able to buy cheap abroad, but fear that, at least for the direct victims of cheaper imports, the gains are swamped by the costs.

Semancíková (2016) brought the point that underpins the WTO overview as she states that it can be useful in many ways, and as per the WTO overview it can be a better utilization of the states' resources due to better production conditions thus reaching comparative advantages. Another one is using the economy of scale that would boost levels of wages, efficiency and resource allocation and these ones are known as the static gains of trade. The dynamic gains of trade are also examined by Semancíková (2016), such as the progress of the total factor productivity through learning by doing and enlargement of human capital. In conclusion, international trade is developed from an outside environment, applicable trade strategy and arrangement of trade patterns.

\subsection{Economic Growth}

Economic growth explains an upturn in real GDP - an increase in the value of national production, revenue, and 
spending. Basically, the advantages of economic growth are higher living standards - higher real incomes and the ability to devote more resources to areas like health care and education. The debates on Economic Growth are in fact known from years ago, in the 50s Robert Solow developed a model of economic growth. The neoclassical theory of economic growth that focuses on capital, labour, and technical progress or as some neoclassical scholars might consider, it is determined by technological development., which is different from the classical Growth theory that focuses on the reduction of the population and the scarcity of resources. It was influenced by Thomas Malthus, even though, the Mercantilist theory contends that a large population helps the economy. Kishtainy, et al. (2015) brought up the Karl Marx disagreement on Malthus's idea, characterizing him as a reactionary defender of the status quo. However, classical economists think that provisional increment in GDP per person may result in population explosion. The classical Growth theory does not consider any sort of role played by any regional grouping or trade union when it comes to wage determination. Stonecash et al. (2000) noted the question that can explain the issue of growth in GDP and population growth; they stated that decreasing the population growth is commonly thought to be one way in which less developed countries could try to increase their level of living. It is explained based on the reasons that quick growth in the number of labourers influences the other elements of production to be distributed more lightly.

The Solow's studies resumed with three main concerns in relation to what really happens to growth. Firstly, he questions what drives technological upgrade in the countries as such, the flow of innovations is a big part of growth for the big countries. Secondly, he mentions the growth after countries get to their balanced growth path, meanwhile it may perhaps have already happened for some of the wealthier countries. Finally, those on the way to the balanced growth path, might be upgrading their technologies faster than those already there (Barnerjee and Duflo, 2019). In addition, Robert Lucas contributed to the Endogenous theory, as such the results of growth are internal and he had brought up the issues of physical and human capital because of an increase on growth, he focuses on human capital accumulation. Paul Romer also emphasized on the population growth and capital accumulation, which therefore means that the economic growth is a result of internal forces, and not external ones. Stonecash et al., (2000) and Amaral, et al. (2007) also stated the same thing.

The research looks at the neoclassical theory and, the endogenous growth theory that refers to constant returns to capital will be part of the discussion as well. Nevertheless, Zahonogo (2016) discussed on the fact that endogenous growth models postulate that, the impact of trade to economic growth varies depending on whether the power of comparative advantage turns the economy's resources towards actions that cause long-run growth or away from such actions.
Furthermore, he suggests that theories indicate that, due to technological or financial constraints, less-developed countries may lack the social capability required to adopt technologies developed in more advanced economies. Hence, he concludes that the growth effect of trade may differ according to the level of economic development.Romer (1986) Brings some studies on the so-called new growth theory which is related to whether import raises or lowers the growth rate of a country which is believed to depend on the pattern of imports and exports (Lucas, 1988).

Additionally, this main debate is still considered empiric and is brought up by Rodriguez and Rodrik, whereby they reviewed studies of Dollar et al. (2001) and back to Edwards (1998) and found out about a strong negative relationship in the data between trade and growth. On the other hand, Harrison and Hanson showed that the studies of Sach and Warner (1995) is reflected more, from the gain of macroeconomic stability rather than trade reform. Talukder (2013) showed that, openness to trade or trade liberalisation forces domestic firms to be more competitive and reduces their market power that may be built up in protected markets. Kneller et al. (2008) brought a paper that addressed both these areas, by studying the type of heterogeneity in growth performance among states of liberalisation using a difference-in-difference approach. From the study they have found results that show that, in aggregate there appears to be a positive but small impact of trade liberalisation on growth. They also stated that empirical examination of this heterogeneity shows that a one-size-fits-all policy is not certainly the most effective and suggest that a case-by-case approach is more appropriate.

Zahonogo (2016) explained that the potential growth effects of trade liberalisation are well known. While the intermediate impact is likely to be negative, as resources become redundant in areas of comparative disadvantage, their eventual reallocation into areas of comparative advantage will increase the growth rate.Evidence has shown that extreme protocols limit growth because incomes are prevented from moving into the most productive areas and to the most efficient companies inside these areas (Bolaky and Freund, 2006) and that organizations can help clarify the conglomeration in the trade growth relationship.

Figure 3.1 Trades and Growth Overview

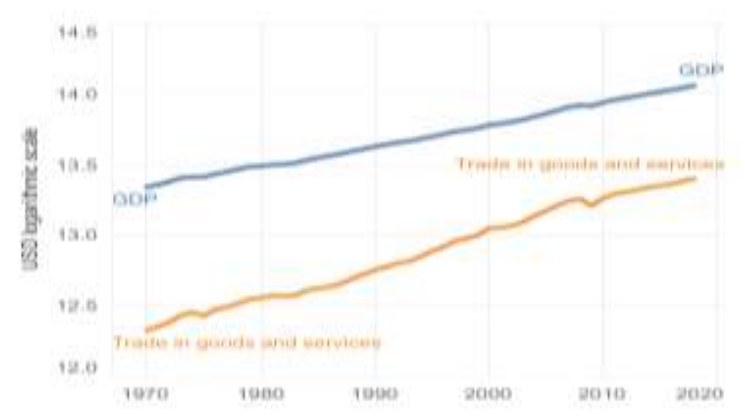

Source: OECD 
The above figure 3.1 from an OECD report analysis shows an overview of the Trade and Growth globally, i.e., a simple analysis that clearly tells us that the more trade goes up the more is the growth, globally. This is an analysis that gives us an understanding of what economists and scholars have been pointing out in a sort of basic analysis. Even though some argue that this analysis is somehow not robust, and the growth might be influenced by many different variables, also for some academicians it is seen that this approach is not well seen for a specific country.

\subsection{Empirical Evidence on the relationship of trade and economic growth}

A study carried out by Sikwila et al. (2014) on South Africa's economy discovered that trade openness increases economic growth, the study was based on the co-integration technique. Even though, many studies were based on a cross-country research or multiple countries studies, authors such as Yusuf et al. (2013) brought up a research that focused on the case of Nigeria, and it was found out that openness to trade does not bring development or does not reduce poverty. Nurudeen et al. (2012) conducted a study based on Nigeria itself and it resulted in a negative and significant effect on economic growth and the study was focused on human capital development, international capital inflows and debt services as added variables. Mallick et al. (2019) evaluated if the trade openness affects the economic growth of India, based on an asymmetric error-correction model threshold co-integration from the pre-trade and post-trade reforms period and it confirmed the evidence of the asymmetric error-correction. However, another study focused on countries within SADC by Moyo and Khobai (2018) revealed that trade openness has a negative impact on economic growth in the long run.

Talukder (2013) mentioned the work of Chang et al. (2009) which conducted rigorous regression analyses using data from 82 countries to observe how growth-effect of trade liberalisation might depend on a variety of the country's characteristics such as educational investment, financial depth, macroeconomic price stability, public infrastructure, governance, labour market flexibility, and ease of a firm's entry or exit. They concluded that removal of barriers to trade would need to be accompanied by complementary reforms in non-trade areas, for improving productivity and growth. Furthermore, the impacts of trade liberalisation might differ depending on the existence and degree of distortions in nontrade institutions, as well as on the feasibility of removing those distortions.

Ahmed et al. (2008) brought an observation that trade liberalisation ensured a positive and significant effect on financial and trade related reforms and these worked to enhance market efficiency, reduced distortions in price and fostered Africa's competitiveness and access to the global market; therefore, encouraging inflow of capital and expansion of exports. Yeboah et al. (2012) showed that in the 1970s, Africa already had a growing fiscal deficit, a current account imbalance and an overvalued exchange rate and all these were supported by project aids and loans at an interest rate of zero or even negative due to bad decisions made by governments to ration credit and foreign exchange instead of increasing the money supply. Yeboah and Akuffo (2012) opined that this resulted in weak market institutions. GDP growth rates in Africa have shown little or no improvement, but countries that adopted trade liberalisation and export-led growth strategies have seen some improvement (Ahmed and Messinis, 2008).

Mallick et al. (2019) noted the point that there are many of the empirical studies that have used cross-country growth regressions to test the endogenous growth theory to examine the link between trade openness and economic growth. They mention the work of Edwards (1998) as well as Rodriguez and Rodrik (2001). Therefore, various scholars have used different procedures to assess the impacts of trade openness on economic growth as per Sach and Warner (1995). Likewise, Mallick et al. (2019) once again mentioned that the Trade restrictiveness index was developed by Anderson and Neary (1992) which in principle combines the influences of both tariffs and non-tariff barriers. Nevertheless, they assumed that due to its non-availability in many large samples of countries, some existing studies have used the available data to measure trade openness, and some other studies have made up indices as per Dollar (1992). Additionally, it is seen that many studies have used trade shares in GDP (exports and imports divided by GDP) and found a positive relationship between trade openness and economic growth, Dollar (1992). Moreover, Mallick et al. (2019) concluded that empirical evidence shows that in the long run, more export-oriented countries experience higher economic growth.

Chang, and Loayza (2009) developed a work that found out that the growth effect of openness is significantly positive if certain complementary reforms are undertaken. They also opined that the interaction results are significant in both the numerical and economic sense, and opposed to several changes, even including the measure of openness. Their estimates indicate that openness can decrease or boost growth, depending on the status of the complementary reforms. Nevertheless, their doctrine is based on the question of, whether the progress in implementing reforms has been considerable in recent decades, and if they found that the growth effect of openness is likely to have been positive in the most recent period of their sample. Developments show more results with a positive impact, and some studies have identified a positive association between trade openness and economic growth (Chang and Loayza, 2009). However, others have found no link, or even a negative association, but it is also needed to clarify that theempirical assessments are as inconclusive as the theoretical angles. The literature is uncertain partly because different analysts use different alternatives for liberalisation or trade openness and rely on different methodologies. The evidence for growth improvements through trade liberalisation presents mixed 
effects because of difficulties with misspecification and the diversity among the liberalisation indices used (Zahonogo, 2016).Bigsten et al. (2000) conducted studies with focus in Ghana, Kenya and Zimbabwe and they described exports as having a positive effect on growth. Yeboah et al. (2012) stated that trade is not just exports and imports, but also other factors such as foreign direct investment (FDI) which impacts productivity and serves as a catalyst for economic development through enhancing job creation and trade growth through the inflow of capital stock.

In general, Semancíková (2016) explained that in the previous years the authors have mostly been focusing on empirical studies, analysing the long-term link between trade, trade openness and economic growth in countries that have experienced a high level of trade openness and liberalisation and she brought up an overview of the main empirical studies that were developed to explain the relationship between trade or openness to trade and economic growth.

Table 3.1 Overview of selected empirical studies

\begin{tabular}{|c|c|c|c|c|}
\hline Author(s) & Variables & Methods & Sample & Conclusion \\
\hline $\begin{array}{c}\text { Balassa } \\
(1978)\end{array}$ & $\begin{array}{c}\text { Total exports, } \\
\text { GNP } \\
\text { Manufactured } \\
\text { exports } \\
\text { Manufactured } \\
\text { GNP } \\
\text { Real income per } \\
\text { person }\end{array}$ & $\begin{array}{l}\text { Spearman } \\
\text { rank } \\
\text { correlation } \\
\text { coefficient }\end{array}$ & $\begin{array}{c}11 \\
\text { developin } \\
\mathrm{g} \\
\text { countries }\end{array}$ & $\begin{array}{l}\text { Findings } \\
\text { support } \\
\text { positive and } \\
\text { indirect } \\
\text { effects of } \\
\text { exports on } \\
\text { GNP. }\end{array}$ \\
\hline $\begin{array}{l}\text { Frankel } \\
\quad \& \\
\text { Romer } \\
(1999)\end{array}$ & $\begin{array}{l}\text { Imports, exports } \\
\text { GDP } \\
\text { Population, area } \\
\text { Proximity }\end{array}$ & $\begin{array}{l}\text { The gravity } \\
\text { model of } \\
\text { bilateral } \\
\text { trade }\end{array}$ & $\begin{array}{l}63 \text { world } \\
\text { countries }\end{array}$ & $\begin{array}{c}\text { Internationa } \\
1 \text { trade and } \\
\text { within- } \\
\text { country } \\
\text { trade have } \\
\text { positive } \\
\text { impact on } \\
\text { income. }\end{array}$ \\
\hline $\begin{array}{c}\text { Irwin \& } \\
\text { Tervio } \\
(2000)\end{array}$ & $\begin{array}{c}\text { The same as } \\
\text { Frankel \& Romer } \\
\text { (1999) }\end{array}$ & $\begin{array}{c}\text { Adjustment } \\
\text { of Frankel \& } \\
\text { Romer } \\
\text { (1999) } \\
\text { methodology } \\
\text { with 2SLS } \\
\text { estimation }\end{array}$ & $\begin{array}{l}62 \text { world } \\
\text { countries }\end{array}$ & $\begin{array}{l}\text { The results } \\
\text { support the } \\
\text { findings of } \\
\text { Frankel \& } \\
\text { Romer } \\
\text { (1999) that } \\
\text { has impact } \\
\text { on income. }\end{array}$ \\
\hline $\begin{array}{l}\text { Parikh \& } \\
\text { Stirbu } \\
(2004)\end{array}$ & $\begin{array}{c}\text { GDP } \\
\text { Current account } \\
\text { Openness } \\
\text { indicator } \\
\text { Investment rate }\end{array}$ & $\begin{array}{l}\text { Panel data } \\
\text { approach and } \\
\text { cross session } \\
\text { analysis }\end{array}$ & $\begin{array}{c}42 \\
\text { developin } \\
\mathrm{g} \\
\text { countries }\end{array}$ & $\begin{array}{c}\text { Liberalisatio } \\
\text { n and } \\
\text { openness } \\
\text { have a } \\
\text { positive } \\
\text { effect on } \\
\text { economic } \\
\text { growth and } \\
\text { liberalisatio } \\
\text { n has a } \\
\text { negative } \\
\text { effect on } \\
\text { trade } \\
\text { deficits. }\end{array}$ \\
\hline $\begin{array}{l}\text { Dollar \& } \\
\text { Kraay } \\
(2004)\end{array}$ & $\begin{array}{c}\text { Real GDP per } \\
\text { capita } \\
\text { Import, export, } \\
\text { GDP } \\
\text { Population, tariffs }\end{array}$ & $\begin{array}{l}\text { The standard } \\
\text { growth } \\
\text { regression } \\
\text { with the } \\
\text { adoption of }\end{array}$ & $\begin{array}{c}72 \\
\text { developin } \\
\mathrm{g} \\
\text { countries } \\
29 \text { rich }\end{array}$ & $\begin{array}{c}\text { The result } \\
\text { confirms a } \\
\text { strong } \\
\text { positive } \\
\text { relationship }\end{array}$ \\
\hline
\end{tabular}

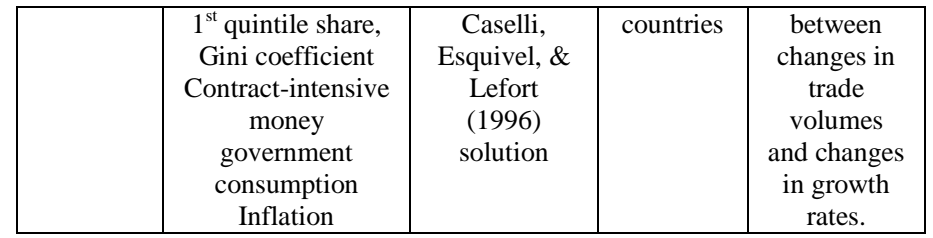

Source: Semancíková (2016)

\section{IV.CONCLUSIONS}

Based on this exhaustive examination for the clear understanding of the impact of trade and growth, we bring the results of the studies of Harrisson and Tang (2004) which brings up a systematic comprehension from two perspective and we can see as follows:

i. Notwithstanding these criticisms, it is safe to say that most authors agree on the following: Firstly, that trade protection is not good for economic growth. Even Rodriguez and Rodrik themselves state in their paper that they have seen no credible evidence to support the notion that trade protection is good for economic growth, at least for the post - 1945 period.

ii. Secondly, trade openness is not sufficient for growth. Rodriguez Rodrik argue in their paper: that researchers and policymakers have been overstating the systematic evidence in favour of trade openness, when what is necessary is to further identify the connection between trade and economic growth.

Additionally, given the hypothetical foundation supporting the benefits of trade and the instrument prompting growth performance of specific countries, it emphasized on the need of mixing the theoretical framework of trade relations which reflect on the need for a trade policy that is dichotomous from exchange as such. From this, it is underlined that countries can explore the gains from trading together, but then, that cannot be applied as a reason to encourage what Silajdzic and Mehic (2018) call a 'passive' trade liberalisation policy per se. The findings from many papers have given us different views but most of them show that trade and in particular export-led growth are commonly viewed as important determinants of the growth process, but the trade policy is subject to a lot of disagreement. Barnerjee and Duflo (2019) show that there is a voluminous literature that focuses on the question if trade liberalisation can bring growth, because of the importance of free trade among scholars. The answers run the gamut from very positive assessment of the effect of trade on GPD to much more sceptical positions, though it must be said that there is little or no evidence for strongly negative effects.

Furthermore, Keho and Wang (2017) showed that the real effect of trade also depends on the level of financial development and inflation. They state that openness to trade has a negative effect on growth in countries with low financial development but has inconsequential impact in countries with high financial development. They also found that trade openness is conducive to economic growth in low-inflation countries but has a minor impact on growth in high-inflation 
countries. Sheikh and Masood (2020) agreed that trade remains a contentious issue in any developmental discussion without a quick fix answer for its capability to affect the economy, culture, and climate. Their study brings the belief that this issue can be resolved by taking alternative welfare measures instead of simple GDP growth rates.

\section{BIBLIOGRAPHY}

[1] Aisen, A., \& Veiga, F. J. (2011). How Does Political Instability Affect Economic Growth. IMF Working Paper, WP/11/12.

[2] Alfaro, L., Chanda, A., Kalemli-Ozcan, S., \& Sayek, S. (2006). How Does Foreign Direct Investment Promote Economic Growth? Exploring the Effects of Financial Markets on Linkages. Harvard Business School, 07-013.

[3] Amaral, J. F., Louçã, F., Gonçalo, C., Fontainha, E., Ferreira, C., \& Santos, S. (2007). Introdução a Macronomia. Lisboa: Escolar Editora.

[4] Banu, I. M. (2013). The Impact of Credit on Economic Growth in the Global Crisis Context. Procedia Economics and Finance, 2530.

[5] Barnerje, A., Gopinath, G., Raghuram, R., Sharma, M. S., Bhandari, P., Chinoy, . . Somanathan, E. (2019). What the Economy needs to know. New Delhi: Juggernaut Books.

[6] Barnerjee, A. V., \& Duflo, E. (2019). Good Economics for hard times. New Delhi: Juggernaut Books.

[7] Begg, D., \& Ward, D. (2009). Economic for Business . Berkshire: McGraw-Hill Higher Education.

[8] Bigsten, A., Collier, P., Dercon, S., Fafchamps, M., Gauthier, B., \& Gunning, J. (2000). Exports and FirmLevel Efficiency in African Manufacturing. Center for the Study of African Economies. Oxford University.

[9] Bolaky, B., \& Freund, C. (2006). Trade, Regulations, and Growth CONFERENCE ON TRADE AND GROWTH RESEARCH DEPARTMENT IMF.

[10] Chang, R., Kaltan, L., \& Loayza, N. V. (2009). Openness can be good for growth: The role of policy complementarities. Journal of Development Economics, 33-49.

[11] Deodhar, S. Y. (2018). Day to Day Economics. Haryana: Penguin Random House.

[12] Dollar, D. (1992). Otward-oriented developing Economies Really Do Grow More Rapidly: Evidence from 95 LCDs, 1976-1985. In Economic Development and Cultural Change (p. 523). Global.

[13] Dollar, D., \& Kraay, A. (2001). Growth is Good for the Poor. The World Bank Development Research Group Macroeconomics and Growth, 56.

[14] Edwards, S. (1998). Openness, outward orientation, trade liberalization and economic performance in developing countries. NATIONAL BUREAU OF ECONOMIC RESEARCH.

[15] Edwards, S. (1998). Trade orientation, dirstortions and growth in developing courties. National Bureau of Economic Research, 48.

[16] Gries, T., \& Redlin, M. (2010). Trade Openness and Economic Growth: A Panel Data Analysis . University of Paderborn.

[17] Harrisson, A., \& Tang, H. (2004). Liberalization of trade: why so much controversy? Munich Personal RePEc Archive.

[18] Hillman, A. L. (2008). Tade Liberalization and Globalization. In C. K. Rowley, \& F. G. Schneider, Readings in Public Choice and Constitutional Political Economy.

[19] Kasidi, F., \& Mwakanemela, K. (2013). Impact of inflation on economic growth: a case study of Tanzania. Asian Journal of Empirical Research, 363-380.

[20] Keho, Y., \& Wang, M. G. (2017). The impact of trade openness on economic growth: The case of Cote d'Ivoire. Cogent Economics \& Finance.

[21] Kishtainy, N., Abbot, G., Farndon, J., Kennedy, F., Meadway, J., Wallace, C., \& Weeks, M. (2015). The Economics Book. London: Penguin Random House.

[22] Kneller, R., Morgan, C. W., \& Kanchanahatakij, S. (2008). Trade Liberalisation and Economic Growth. The World Economy, 701719 .
[23] La Dehesa, G. (2000). Comprender Globalización. Alianza.

[24] Lucas, R. E. (1988). ON THE MECHANICS OF ECONOMIC DEVELOPMENT. Journal of Monetary Economics, 3-42.

[25] Mallick, L., \& Ranjan Behera, S. (2019, January 26). Does trade openness affect economic growth in India? Evidence from threshold cointegration with asymetric adjustment. Retrieved from Contigent Economic \& Finance: https://www.tandfonline.com/doi/full/10.1080/23322039.2020.178 2659

[26] Moyo, C., \& Khobai, H. (2018). Trade openness and economic growth in SADC countries. Munich Personal RePEc Archive.

[27] Nurudeen, A., Obi, B., Wafe, G., Jimaza, M., Abdullahi, U., \& Gana, U. (2012). Trade Opennness Economic Growth nexus: Empirical evidence from Nigeria. Economic Journal of Nepal, 35.

[28] Pigka-Balanika, V. (2013, February 30). The Impact of Trade Openness on Economic Growth. Retrieved Setember 14, 2020, from Erasmus University Thesis Repository: https://thesis.eur.nl/pub/15905/356613-Pigka-Balanika.pdf

[29] Pritchett, L. (1996). Measuring Outward Orientation in the LDCs: Can it be Done? Journal of Development Economics, 49: 309-55.

[30] Rodriguez, F., \& Rodrik, D. (2001). Trade Policy and Economic Growth: A Skeptic's Guide to the Cross-National Evidence. Cambrige.

[31] Rodrik, D. (2017, December 5). Rescuing Economics from Neoliberalism. Boston Reviews, 15.

[32] Romer, P. D. (1986). Increasing Returns and Long-Run Growth . The Journal of Political Economy.

[33] Sach, J., \& Warner, A. (1995). Economic Reform and the Process of Global Integration. Brookings Paper-s on Economic Activity.

[34] Sadeh, T. (2014). The Euro's Effect on Trade. European Union Politics, 215-234.

[35] Semancíková, J. (2016). Trade, Trade opnness and Macroeconomic performance . Elsevier, 10.

[36] Sheikh, A. M., Malik, A. M., \& Masood, R. Z. (2020). Assessing the effects of trade openness on sustainable development: evidence from India. Asian Journal of Sustainability and Social Responsibility.

[37] Sikwila, N., Ruvimbo, N., \& Mosikari, T. (2014). Trade openness and GDP Growth nexus in. Global Journal of Management and Business Research.

[38] Silajdzic, S., \& Mehic, E. (2018). Trade Openness and Economic Growth: Empirical Evidence from Transition Economies. IntechOpen.

[39] Silva, S., JMC, \& Tenreyro, S. (2011). Further Simulation Evidence on the Performance of the Poisson Pseudo-Maximum Likelihood Estimator. Economics Letters, 220-222.

[40] Stensnes, K. (2006). Trade Openness and Economic Growth, Do institutions matter? Norsk Utenrikspolitisk Institutt - NUPI, 72.

[41] Stiglitz, J. (2012). Globalization and its Discontents. Haryana: Penguin Books.

[42] Stonecash, R. E., Gans, J. S., King, S. P., \& Mankiw, N. G. (2000). Principles of Macroeconomics . Sydney: Harcourt.

[43] Talukder, D. (2013). Gains and losses from trade liberalisation: a theoretical debate and empirical evidence. ICL Business School, 93-103.

[44] Tinbergen, J. (1962). haping the World Economy; Suggestions for an International Economic Policy. Twentieth Century Fund.

[45] Yeboah, O., Naanwaab, C., Saleem, S., \& Akuffo, A. (2012). Effects of Trade Openness on Economic Growth: The Case of African Countries. Agribusiness, Applied Economics and Agriscience Education- NC A\&T, 4-7.

[46] Yusuf, M., Malarvizhi, A., \& Khin, A. (2013). Trade Liberalization Economic Growth and Poverty Reduction in Nigeria. International Journal of Business and Management, 4347.

[47] Zahonogo, P. (2016). Trade and economic growth in developing countries: Evidence from sub-Saharan Africa. Journal of African Trade, 41-56. 